\title{
ANALISIS PENGARUH PRODUK, HARGA, PROMOSI DAN SALURAN DISTRIBUSI TERHADAP PERILAKU PEMBELIAN KONSUMEN PADA PRODUK MIE INSTAN INDOMIE DI YOGYAKARTA
}

\author{
Irfan Anjas Purwo \\ irfan1400011033@webmail.uad.ac.id \\ Universitas Ahmad Dahlan \\ Fitroh Adhilla \\ fitauad@yahooo.com \\ Universitas Ahmad Dahlan
}

\begin{abstract}
ABSTRAK
This study aims to determine the effect of the product, price, promotion and distribution channels on the buying behavior of Indomie instant noodle consumers in the city of Yogyakarta. The dependent variable used is Purchasing Behavior, while the independent variables are Product, Price, Promotion and Distribution Channels. The population in this study is the people of the city of Yogyakarta, aged 18 years and over and have bought Indomie instant noodles which were then taken as many as 95 samples. The instrument test used was Confirmatory Factor Analysis (CFA) with a confidence level of 5\% and hypothesis testing was performed using the t test and $\mathrm{F}$ test. The results of this study showed that the product had a positive and significant effect on purchasing behavior not proven with a probability value of 0.208 greater than $\alpha 0.05$. Price has a positive and significant effect on buying behavior is not proven with a probability value of 0.147 greater than $\alpha 0.05$. Promotion positive and significant effect on purchasing behavior is proven, with a probability value of 0.002 smaller than $\alpha 0.05$ and the distribution channel has a positive and significant effect on purchasing behavior not proven, with a probability value of 0.186 greater than $\alpha$ 0.05. While simultaneously the independent variable has a significant effect on Purchasing Behavior, with a significance value of 0.000 less than $\alpha 0.05$. The coefficient of determination is 0.381 which means that all independent variables of $38.1 \%$ can explain the dependent variable of buying behavior while the remaining $61.9 \%$ is influenced by other factors.
\end{abstract}

Keywords: Product, Price, Promotion, Distribution Channels and Purchasing Behavior.

\section{PENDAHULUAN}

Perkembangan industri makanan di Indonesia ditandai dengan banyaknya jenis dan merek makanan dalam kemasan yang beredar di pasar. Aktivitas masyarakat yang mulai sibuk dan minimnya waktu untuk mengolah makanan menjadi salah satu penyebab masyarakat banyak memilih mie instan sebagai salah satu alternatif pilihan untuk membantu memenuhi kebutuhan energi pada tubuh. Sehingga memacu para pengelola perusahaan untuk dapat berpikir secara kreatif dan inovatif agar selalu memberikan diferensiasi, serta keunggulan bagi perusahaannya dibandingkan dengan para pesaingnya. Perusahaan dituntut tidak hanya sekedar mengembangkan produk yang baik, menawarkan dengan harga yang menarik, dan membuatnya mudah diperoleh oleh pelanggan yang membutuhkan, perusahaan juga perlu mengembangkan promosi pemasaran yang efektif terutama kepada para konsumen, inovasi, dan dampak sosial. 
Salah satu tugas utama dan tanggung jawab yang berkecimpung di bidang manajemen pemasaran adalah memikirkan desain produk. Produk yang dibuat adalah produk yang dibutuhkan konsumen, karena itu bagian pemasaran seolah-olah bertugas sebagai "mata" perusahaan, yang harus selalu jeli dalam mengamati kebutuhan konsumen. Kotler dan Keller (2009:4) mendefinisikan produk adalah sesuatu yang dapat ditawarkan kepada pasar untuk memuaskan suatu keinginan atau kebutuhan, termasuk barang fisik, jasa, pengalaman, acara, orang, tempat, properti, organisasi, informasi dan ide. Sedangkan menurut Tjiptono (2008:95) produk adalah segala sesuatu yang dapat ditawarkan produsen untuk diperhatikan, diminta, dicari, dibeli, digunakan, atau dikonsumsi pasar sebagai pemenuhan kebutuhan atau keinginan pasar yang bersangkutan.

Harga adalah jumlah uang yang diperlukan sebagai penukar berbagai kombinasi produk dan jasa. Menurut Tjiptono (2008:151) harga adalah satuan moneter atau ukurang lainnya (termasuk barang dan jasa lainnya) yang ditukarkan agar memperoleh hak kepemilikan atau penggunaan suatu barang atau jasa. Sedangkan menurut Kotler dan Keller (2009:67) harga adalah nilai uang untuk menghasilkan pendapatan dan biaya. Harga-harga produk dibuat beragam dan relatif murah, tujuannya agar harga-harga tiap produk dapat dijangkau oleh segala strata sosial. Pada umumnya juga konsumen sering menerapkan prinsip ekonomi dalam membeli sebuah produk, yaitu dengan pengeluaran atau pengorbanan yang relatif kecil untuk mendapatkan keuntungan yang relatif lebih besar. Konsumen ingin memenuhi kebutuhan atau keinginannya dengan sebuah produk barang atau jasa dan pemenuhan ini dalam harapan konsumen dapat sebanding nilainya dengan pengorbanan yang dikeluarkan oleh kon

Promosi salah satu variabel di dalam bauran pemasaran yang sangat penting dilaksanakan oleh perusahaan dalam pemasaran produk atau jasanya. Promosi merupakan salah satu faktor penentu keberhasilan suatu program pemasaran. Betapapun berkualitasnya suatu produk, bila konsumen belum pernah mendengarnya dan tidak yakin bahwa produk itu akan berguna bagi mereka, maka mereka tidak akan pernah membelinya. Menurut Kotler dan Keller (2009:172) promosi adalah sarana dimana perusahaan berusaha informasikan, membujuk, dan mengingatkan konsumen secara langsung maupun tidak langsung tentang produk dan merek yang dijual. Menurut Tjiptono (2008:219) promosi adalah aktivitas pemasaran yang berusaha menyebarkan informasi, mempengaruhi atau membujuk, dan atau mmengingatkan pasar sasaran atas perusahaan dan produknya agar bersedia menerima, membeli dan loyal pada produk yang ditawarkan perusahaan yang bersangkutan.

Manajemen pemasaran mempunyai peranan dalam mengevaluasi penampilan para penyalur. Bila perusahaan merencanakan suatu pasar tertentu, yang pertama kali dipikirkan adalah siapa yang akan ditunjuk4 sebagai penyalur di sana, atau berapa banyak yang bersedia untuk menjadi penyalur di daerah itu. Tjiptono (2008:185) mendefinisikan distribusi sebagai kegiatan pemasaran yang berusaha memperlancar dan mempermudah penyampaian barang dan jasa dari produsen kepada konsumen, sehingga penggunaannya sesuai dengan yang diperlukan. Sedangkan menurut Kotler dan Keller (2009:106) distribusi adalah sekelompok organisasi yang saling bergantung dan terlibat dalam proses pembuatan produk atau jasa yang disediakan untuk digunakan atau dikonsumsi.

Indomie merupakan mie instan keluaran produsen PT Indofood CBP Sukses Makmur yang juga merupakan produsen Pop Mie. Mi instan adalah mi yang sudah dimasak terlebih dahulu dan dicampur dengan minyak, dan bisa 
dipersiapkan untuk konsumsi hanya dengan menambahkan air panas dan bumbu-bumbu yang sudah ada dalam paketnya. Mie instan juga memiliki kandungan gizi seperti karbohidrat, protein, vitamin, kalsium, zat besi dan lain sebagainya

Survey Top Brand yang didasarkan pada tiga penilaian yaitu mind share, market share dan commitment share, mie instan Indomie mengalami kenaikan persentase dari tahun ke tahun, tehitung dari tahun 2015 sampai 2017. Mind share, menunjukkan kekuatan sebuah merek dalam benak konsumen dari kategori produk masing-masing. Market share, menunjukkan kekuatan merek di pasar tertentu dalam hal Perilaku Pembelian Konsumen. Serta commitment share, mengindikasikan kekuatan merek dalam mendorong konsumen untuk membeli merek di masa depan.

Tabel 1.1

Data Hasil Top Brand Index

\begin{tabular}{|l|c|c|c|}
\hline \multicolumn{1}{|c|}{ MEREK } & TBI 2016 & TBI 2016 & TBI 2017 \\
\hline Indomie & $75.9 \%$ & $78.7 \%$ & $80.0 \%$ \\
\hline Mi Sedaap & $15.9 \%$ & $12.5 \%$ & $10.8 \%$ \\
\hline Sarimi & $2.7 \%$ & $3.6 \%$ & $3.4 \%$ \\
\hline Supermi & $2.2 \%$ & $3.0 \%$ & $3.2 \%$ \\
\hline
\end{tabular}

Sumber: http://www.topbrand-award.com (diakses tanggal 06 Januari 2018)

\section{Rumusan Masalah}

1. Apakah ada pengaruh positif produk terhadap perilaku pembelian konsumen pada produk mie instan Indomie di Yogyakarta?

2. Apakah ada pengaruh positif harga terhadap perilaku pembelian konsumen pada produk mie instan Indomie di Yogyakarta?

3. Apakah ada pengaruh positif promosi terhadap perilaku pembelian konsumen pada produk mie instan Indomie di Yogyakarta?

4. Apakah ada pengaruh positif saluran distribusi terhadap perilaku pembelian konsumen pada produk mie instan Indomie di Yogyakarta?
5. Produk, harga, promosi dan saluran distribusi sama-sama berpengaruh terhadap keputusan pembelian produk mie instan Indomie di Yogyakarta?

\section{REVIEW LITERATUR DAN HIPOTESIS}

\section{Landasan Teori}

\section{Produk}

Menurut Kotler dan Keller (2009:4) produk adalah sesuatu yang dapat ditawarkan kepada pasar untuk memuaskan suatu keinginan atau kebutuhan, termasuk barang fisik, jasa, pengalaman, acara, orang, tempat, properti, organisasi, informasi dan ide. Sedangkan menurut Tjiptono (2008:95) produk adalah segala sesuatu yang dapat ditawarkan produsen untuk diperhatikan, diminta, dicari, dibeli, digunakan, atau dikonsumsi pasar sebagai pemenuhan kebutuhan atau keinginan pasar yang bersangkutan.

\section{Harga}

Berdasarkan sudut pandang pemasaran, harga adalah satuan moneter yang ditukarkan agar memperoleh hak kepemilikan atau penggunaan suatu barang atau jasa. Sementara itu dari sudut pandang konsumen, harga seringkali digunakan sebagai indikator pengukur nilai dari manfaat yang dirasakan atas suatu barang atau jasa. Menurut Tjiptono (2008:151) harga adalah satuan moneter atau ukuran lainnya (termasuk barang dan jasa lainnya) yang ditukarkan agar memperoleh hak kepemilikan atau penggunaan suatu barang atau jasa. Sedangkan menurut Kotler dan Keller (2009:67) Harga adalah jumlah uang yang diperlukan sebagai penukar berbagai kombinasi produk dan jasa. Menurut Swastha (2002:147) harga adalah sejumlah uang (ditambah beberapa barang kalau mungkin) yang dibutuhkan untuk mendapatkan sejumlah kombinasi dari barang beserta pelayanannya. Sedangkan menurut Umar (2000:32) mendefinisikan 
harga adalah sejumlah nilai yang ditukarkan konsumen dengan manfaat dari memiliki atau menggunakan produk atau jasa yang nilainya ditetapkan oleh pembeli dan penjual melalui tawar-menawar ,atau ditetapkan oleh penjual untuk satu harga yang sama terhadap semua pembeli.

\section{Promosi}

Menurut Tjiptono (2008:219) promosi dapat didefinisikan sebagai suatu bentuk komunikasi pemasaran, komunikasi pemasaran adalah aktivutas pemasaran yang berusaha menyebarkan informasi, mempengaruhi/ membujuk dan/atau mengingatkan pasar sasaran atas perusahaan dan produknya agar bersedia menerima, membeli, dan loyal pada produk yang ditawarkan perusahaan yang bersangkutan.

Menurut Gitosudarmo (2000:237) promosi merupakan kegiatan yang ditunjuk untuk mempengaruhi konsumen agar mereka menjadi kenal akan produk yang ditawarkan oleh perusahaan kepada mereka dan mereka menjadi senang lalu membeli produk itu. Sedangkan menurut Kotler dan Amstrong (2001:49) berpendapat bahwa promosi adalah aktivitas yang mengkomunikasikan keunggulan produk dan membujuk pelanggan, sasaaran untuk membelinya.

\section{Saluran Distribusi}

Menurut Angipora (2002:296) menyatakan bahwa saluran distribusi adalah sekelompok pedagang dan agen perusahaan yang mengkombinasikan antara pemindahan fisik dan nama dan suatu produk untuk menciptakan kegunaan pasar tertentu. Sedangkan menurut Gitosudarmo (2008:253) saluran distribusi merupakan seperangkat lembaga yang melakukan kegiatan untuk menyalurkan, menyebarkan, mengirim serta menyampaikan barang yang di pasarkannya itu kepada konsumen.

\section{Perilaku Konsumen}

Proses psikologis dasar memainkan peranan penting dalam memahami bagaimana konsumen benar-benar membuat keputusan pembelian. Sebelum merencanakan pemasaran, suatu perusahaan perlu mengidentifikasi konsumen, sasarannya dan proses keputusan mereka. Walaupun banyak keputusan pembelian melibatkan hanya satu pengambilan keputusan, keputusan yang lain mungkin melibatkan beberapa peserta yang memerankan peran, pencetus ide, pemberi pengaruh, pengambil keputusan, pembeli dan pemakai. Disini tugas pemasar adalah mengidentifikasi peserta pembelian lain, kriteria pembelian mereka dan pengaruh mereka terhadap pembeli. Program pemasaran harus dirancang untuk menarik seperti halnya pembeli.

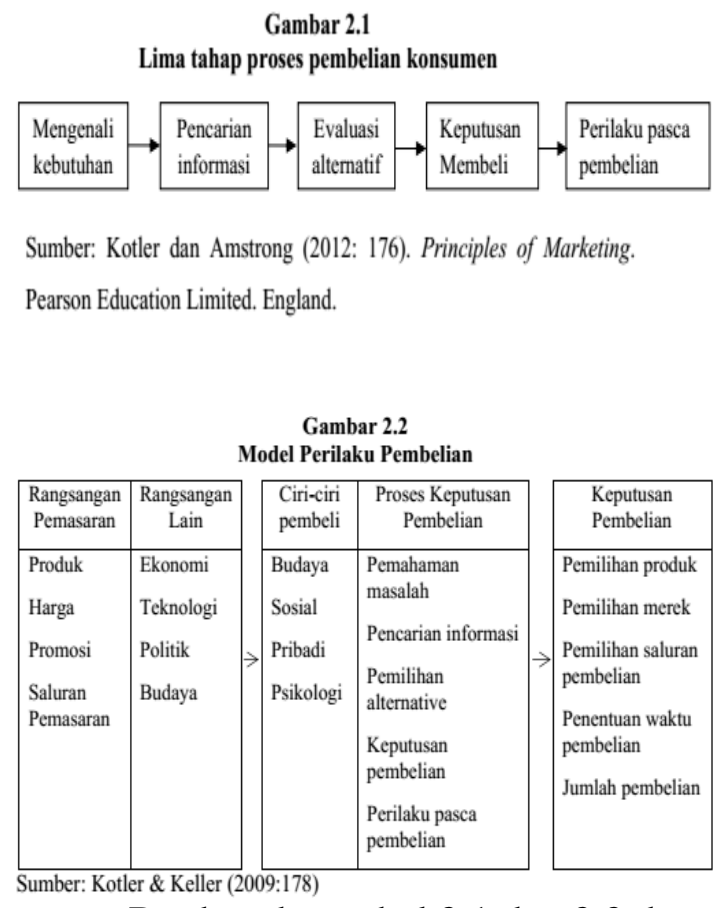

Berdasarkan tabel 2.1 dan 2.2 dapat dijelaskana bahwa perilaku konsumen sebelum membeli suatu produk dapat terbaca dengan alur tersebut. 
Penelitian Terdahulu

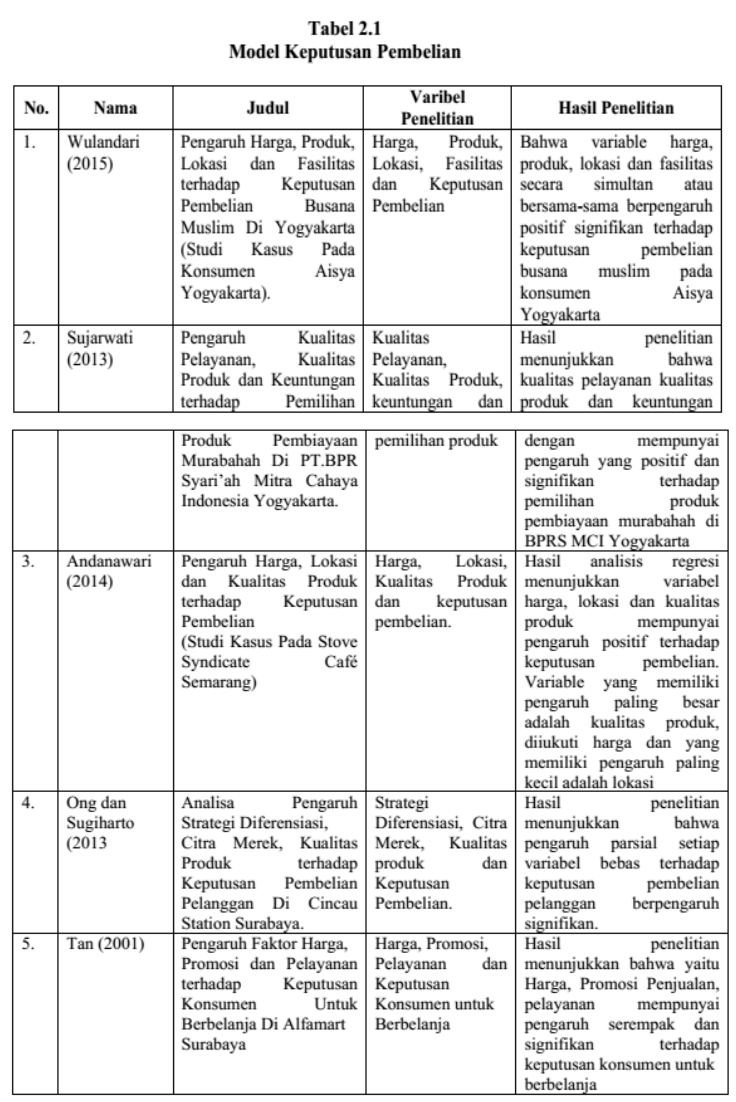

Secara keseluruhan penelitian yang peneliti lakukan memiliki beberapa persamaan dengan penelitian sebelumnya. Hanya saja terdapat perbedaan seperti pada lokasi penelitian (objek), tahun penelitian, jumlah responden serta beberapa variabel penelitiannya. Didalam penelitian ini, peneliti ingin mengkaji lebih dalam mengenai produk harga promosi dan saluran distribusi yang mempengaruhi perilaku pembelian konsumen dalam memutuskan untuk membeli produk mie instan Indomie di Yogyakarta

\section{Hipotesis}

H1: Produk berpengaruh signifikan positif terhadap perilaku pembelian konsumen pada produk mie instan Indomie di Yogyakarta

$\mathrm{H} 2$ : Harga berpengaruh signifikan positif terhadap perilaku pembelian konsumen pada produk mie instan Indomie di Yogyakarta
H3: Promosi berpengaruh signifikan positif terhadap perilaku pembelian konsumen pada produk mie instan Indomie di Yogyakarta

H4: Saluran Distribusi berpengaruh signifikan positif terhadap perilaku pembelian konsumen pada produk mie instan Indomie di Yogyakarta

H5: Produk, Harga, Promosi dan Saluran Distribusi bersama-sama berpengaruh signifikan positif terhadap perilaku pembelian konsumen pada produk mie instan Indomie di Yogyakarta

\section{METODE PENELITIAN}

\section{Populasi dan Sampel}

Populasi menurut Sunyoto (2012:47) berpendapat bahwa populasi adalah jumlah dari keseluruhan objek (satuan atau individu) yang karakteristiknya hendak diduga. Dalam penelitian ini yang menjadi populasi adalah konsumen mie instan Indomie di YogyakartaSampel adalah bagian dari jumlah dan karakteristik yang dimiliki oleh populasi tersebut Sugiyono (2016).

Menurut Sugiyono (2017:118) sampel adalah sebagian dari jumlah dan karakteristik yang dimiliki oleh populasi tersebut. Pengukuran sampel merupakan suatu langkah untuk menentukan besarnya sampel yang diambil dalam melaksanakan suatu penelitian.

Penentuan jumlah sampel minimum dihitung berdasarkan rumus berikut: Ghanimata (2012:45)

$$
\begin{aligned}
& n=(\text { variabel } x \text { indikator variabel }) \\
& n=5 \text { variabel X } 19 \text { indikator } \\
& =95 \text { sampel }
\end{aligned}
$$

Dari perhitungan di atas, maka diperoleh jumlah sampel yang akan diteliti adalah sebesar 90 responden.

\section{Teknik Pengambilan Sampel}

Sampling adalah bagian dari jumlah dan karakteristik yang dimiliki oleh populasi tersebut. Sugiyono (2017:118) 
menyatakan bahwa Teknik sampling adalah merupakan teknis pengambilan sampel. Untuk menentukan sampel yang akan digunakan dalam peneliti.

Metode pengambilan sampel yang digunakan adalah metode Purposive Sampling, yaitu metode pengambilan sampel yang dilakukan dengan menentukan sampel dari populasi yang mempunyai kriteria tertentu.

Data yang akan dianalisis merupakan data hasil pendekatan survei penelitian dari penelitian lapangan dan penelitian kepustakaan, kemudian dilakukan analisa untuk menarik kesimpulan

Dalam penelitian ini alat pengukuran dengan menggunakan kuesioner, dengan menggunakan skala likert. Menurut Sugiyono (2014:134) skala likert yaitu skala yang digunakan untuk mengukur sikap, pendapat dan persepsi seseorang atau kelompok orang tentang fenomena sosial.

Menurut Sugiyono (2014:135) jawaban setiap instumen yang menggunakan skala likert mempunyai gradasi dari sangat positif sampai sangat negatif, yang dapat berupa kata-kata yang diberi skor.

Tabel 3.1

Model Penilaian Skala Likert

\begin{tabular}{|l|c|c|}
\hline Sangat Setuju & SS & 5 \\
\hline Setuju & S & 4 \\
\hline Netral & N & 3 \\
\hline Tidak Setuju & TS & 2 \\
\hline Sangat Tidak Setuju & STS & 1 \\
\hline
\end{tabular}

\section{Jenis dan Sumber Data}

Algifari (2013:9) mendefinisikan sumber primer adalah data yang diperoleh langsung dari objek yang akan diteliti, baik secara langsung datang ke objek maupu melalui angket (kuesioner). Sumber data primer yang digunakan dalam penelitian ini adalah hasil pengisian kuesioner yang berisi pernyataan-pernyataan yang berhubungan dengan topik penelitian oleh responden .
Jenis penelitian ini menggunakan jenis penelitian kuantitatif yang merupakan salah satu jenis penelitian yang spesifikasinya sistematis, terencana dan terstruktur dengan jelas sejak awal hingga pembuatan desain penelitiannya. Dalam penelitian ini peneliti menggunkan konsumen mie instan Indomie di Yogyakarta sebagai sumber data penelitian.

\section{Teknik Pengumpulan Data}

Teknik dalam penelitian ini menggunakan kuesioner. Menurut Sugiyono (2010:199) menyatakan bahwa kuesioner merupakan teknik pengumpulan data yang dilakukan dengan cara memberi seperangkat pertanyaan atau pernyataan yang tertulis kepada responden untuk dijawabnya. Kuesioner ini dimaksudkan untuk memperoleh data tersebut, dengan menggunakan kuesioner yang bersifat tertutup yaitu pertanyaan atau penyataan yang sedemikian rupa sehingga responden dibatasi dalam memberikan jawaban kepada beberapa alternatif saja atau pada satu jawaban saja. Untuk itu peneliti harus mampu membuat teknik yang akan digunakan untuk penelitian.

Dalam penelitian ini kuesioner yang diajukan adalah pernyataan mengenai penilian responden mengenai pengaruh produk, harga, promosi dan saluran distribusi terhadap perilaku pembelian konsumen mie instan Indomie di Yogyakarta.

\section{Definisi Operasional}

Menurut Sugiyono (2014:60) variabel merupakan sesuatu hal yang berbentuk apa saja yang ditetapkan oleh peneliti untuk dipelajari, apa yang akan diteliti oleh peneliti sehingga diperoleh informasi tentang hal tersebut, kemudian ditarik kesimpulannya.

\section{Variabel Dependen}

Dalam penelitian ini yang termasuk variabel terikat adalah keputusan pembelian dengan indikator meliputi: 
a) Pengenalan kebutuhan.

b) Pencarian informasi

c) Evaluasi alternatif.

d) Keputusan membeli.

e) Perilaku pasca pembelian.

\section{Variabel Independen}

1.Produk (X1)

Indikatornya adalah:

a) Kualitas produk.

b) Pembaruan produk.

c) Macam-macam produk.

d) Tampilan produk.

\section{Harga (X2)}

Indikatornya adalah:

a) Penetapan harga jual.

b) Harga sesuai dengan kualitas.

c) Elastisitas harga.

d) Perbandingan harga pesaing merek

\section{Promosi (X3)}

Indikatornya adalah:

a) Jangkauan Promosi.

b) Daya tarik iklan.

c) Kuantitas iklan.

d) Kualitas iklan.

4. Saluran distribusi (X4)

Indikatornya adalah:

a) Kemudahan proses pencarian produk.

b) Ketersediaan produk.

\section{Uji Instrumen}

1. Uji Validitas

Suatu instrumen dinyatakan valid apabila mampu mengukur apa yang diinginkan dan dapat mengungkapkan data dari variabel yang diteliti secara tepat. Pengujian validitas adalah pengujian yang ditujukan untuk mengetehui suatu data dapat dipercaya kebenarannya sesuai dengan kenyataan.

Alat uji validitas dalam penelitian ini adalah dengan confirmatory factor analysis (CFA). Menurut Ghozali (2012:52) CFA berfungsi untuk menguji apakah indikator-indikator pertanyaan yang digunakan dapat mengkonfirmasikan sebuah variable. untuk pengujian CFA peneliti menggunakan program computer yaitu IBMS SPSS Statistic, korelasi antar variabel yang diinginkan adalah diatas 0,5.

2. Uji Reliabilitas

Menurut Ghozali (2012:47) Suatu kuesioner dikatakan reliable atau handal jika jawaban seseorang pada pertanyaan adalah konsisten atau stabil dari waktu ke waktu. Untuk mengetahui tingkat reliabel atas intrumen penelitian, dapat diketahui dengan metode Crombach Alpha dengan menggunakan program computer yaitu IBM SPSS Statistic. Ghozali (2012:47) menyatakan bahwa butir kuesioner dikatakan reliabel (layak) jika cronbach alpha>0.6 dan dikatakan tidak reliabel jika cronbach alpha< 0,06. Semakin tinggi reliabilitas suatu alat ukur maka semakin stabil pula alat ukur tersebut.

\section{Teknik Analisis Data}

1. Analisis Regresi Berganda

Analisis regresi merupakan salah satu analisis yang bertujuan untuk mengestimasi pengaruh variabel bebas dan variabel terikat. Analisis Regresi Linier Sederhana dapat dirumuskan sebagai berikut :

$\mathrm{Y}=\alpha+\beta 1 \mathrm{X} 1+\beta 2 \mathrm{X} 2+\beta 3 \mathrm{X} 3+\beta 4 \mathrm{X} 4+\mathrm{e}$

Dengan keterangan :

$\mathrm{Y}=$ Perilaku Pembelian Konsumen

$\alpha=$ Konstanta

$\beta 1=$ Koefisien Produk

$\beta 2=$ Koefisien Harga

$\beta 3=$ Koefisien Promosi

$\beta 4=$ Koefisien Saluran Distribusi

$\mathrm{X} 1 \mathrm{=}$ Produk

$\mathrm{X} 2=$ Harga

$\mathrm{X} 3$ = Promosi

$\mathrm{X} 4=$ Saluran distribusi

$\mathrm{e}=$ error

\section{Uji Hipotesis}

\section{Uji Parsial (Uji T)}

Menurut Ghozali (2011:98) uji $t$ pada dasarnya menunjukan seberapa jauh pengaruh satu variabel penjelas atau bebas secara individual dalam menerangkan variasi variabel terikat. 
Uji $t$ digunakan urnuk menguji signifikansi hubungan antara variabel $\mathrm{X}$ dan $\mathrm{Y}$, apakah variabel X1, X2, X3, X4 (Produk, Harga, Promosi dan Saluran Distribusi) benar-benar berpengaruh terhadap variabel Y (perilaku pembelian konsumen) secara terpisah atau parsial. Hipotesis dalam pengujian ini adalah:

H0: Produk tidak berpengaruh positif terhadap perilaku pembelian konsumen.

H1: Produk mempunyai pengaruh positif terhadap perilaku pembelian konsumen.

H0: Harga tidak berpengaruh positif terhadap perilaku pembelian konsumen.

$\mathrm{H} 2$ : Harga mempunyai pengaruh positif terhadap perilaku pembelian konsumen.

H0: Promosi tidak berpengaruh positif terhadap perilaku pembelian konsumen.

H3: Promosi mempunyai pengaruh positif terhadap perilaku pembelian konsumen.

H0: Saluran Distribusi tidak berpengaruh positif terhadap perilaku pembelian konsumen.

H4: Saluran Distribusi berpengaruh positif terhadap perilaku pembelian konsumen.

Pengujian dilakukan dengan menggunakan tingkat signifikan $(\alpha) 5 \%$. Ketentuan dalam menganalisa adalah dengan cara sebagai berikut:

1. Jika nilai sig. $>0,05$, maka $\mathrm{H} 0$ diterima dan $\mathrm{Ha}$ ditolak, artinya tidak ada pengaruh yang signifikan variabel bebas terhadap variabel terikat.

2. Jika nilai sig. < 0, 05, maka Ha diterima dan H0 ditolak, artinya ada pengaruh yang signifikan antara variabel bebas terhadap variabel terikat.

\section{Uji Koefisien Determinasi $\left(\mathbf{R}^{2}\right)$}

Koefisien determinasi yaitu mengukur seberapa jauh kemampuan model dalam menerangkan variasi variabel dependen. Nilai koefisien determinasi adalah antara nol dan satu. Nilai R2 yang kecil berarti kemampuan variabel-variabel independen dalam menjelaskan variasi variabel dependen sangat terbatas. Menurut Ghozali (2012:97) koefisien determinan R2 merupakan alat untuk mengukur seberapa jauh kemampuan model dalam menerangkan variasi variabel dependen.

\section{Uji signifikansi simultan (uji F)}

Menurut Ghozali (2001:44) Uji F statistic pada dasarnya menunjukkan apakah semua variable bebas yang dimasukkan dalam model regresi mempunyai pengaruh secara bersamasama terhadap variable terikat.

Kaidah pengambilan keputusan dalam uji $F$ dengan menggunakan IBM SPSS Statistic adalah:

Jika probabilitas $>0,05$ maka Ho diterima. Jika probabilitas < 0, 05 maka Ho ditolak

\section{HASIL PENELITIAN DAN PEMBAHASAN}

\section{Data Hasil Penelitian}

Dari kuesioner yang disebarkan peneliti melalui Google Form dapat terkumpulkan sebanyak 95 paket kuesioner dan dinyatakan rusak tidak ada. Sehinggan kuesioner yang dapat diteliti sebanyak 95 paket kuesioner.

\section{Gambaran Umum Responden}

Gambaran umum responden penelitian akan diuraikan secara deskriptif dan dibantu dengan penyajian dalam bentuk tabel dari jumlah responden dengan membagi kedalam beberapa tabel yaitu jenis kelamin, usia, pendidikan terakhir dan pekerjaan. Diharapkan dengan bantuan penyajian dalam bentuk tabel dapat memberikan gambaran yang cukup jelas tentang kondisi responden dan kaitannya dengan masalah-masalh dan tujuan penelitian. 
a. Responden Berdasarkan Jenis Kelamin

Tabel 4.1

Responden Berdasarkan Jenis Kelamin

\begin{tabular}{|l|c|c|}
\hline \multicolumn{1}{|c|}{ Jenis Kelamin } & Frekuensi & Persentase \\
\hline Pria & 34 & $35.8 \%$ \\
\hline Wanita & 61 & $64.2 \%$ \\
\hline Total & 95 & $100 \%$ \\
\hline
\end{tabular}

Sumber: Data primer, (2018)

Dari tabel diatas dapat diketahui bahwa keseluruhan responden yang ikut berpartisipasi didominasi oleh responden wanita sebanyak 61 responden $(64.2 \%)$ dan responden pria sebanyak 34 responden $(35.8 \%)$

b. Responden Berdasarkan Usia Tabel 4.2 Responden Berdasarkan Usia

Responden Berdasarkan Usia
\begin{tabular}{|l|c|c|}
\hline Kelompok Usia & Frekuensi & Persentase \\
\hline 18-25 Tahun & 89 & $93.7 \%$ \\
\hline 26-35 Tahun & 3 & $3.1 \%$ \\
\hline 36-45 Tahun & 1 & $1.1 \%$ \\
\hline Diatas 46 Tahun & 2 & $2.1 \%$ \\
\hline Total & 95 & $100 \%$ \\
\hline
\end{tabular}

Sumber: Data primer, (2018)

Dari tabel diatas dapat dilihat bahwa usia responden terbanyak adalah pada usia 18-25 tahun yaitu sebanyak 89 responden $(93.7 \%)$, kemudian usia 26-35 tahun sebanyak 3 responden $(3.1 \%)$, usia 36-45 tahun sebanyak 1 responden $(1.1 \%)$ dan terakhir usia diatas 46 tahun sebanyak 2 responden $(2.1 \%)$. Data ini menunjukan mayoritas responden adalah yang berada pada usia antara 18-25 tahun.

c. Responden Berdasarkan Pendidikan Terakhir

Responden Berdasarkan Pendidikan Terakhir

\begin{tabular}{|l|c|c|}
\hline Pendidikan Terakhir & Frekuensi & Persentase \\
\hline SMP & 2 & $2.1 \%$ \\
\hline SMA & 66 & $69.5 \%$ \\
\hline Sarjana / Diploma & 27 & $28.4 \%$ \\
\hline Total & 95 & $100 \%$ \\
\hline
\end{tabular}

Sumber: Data primer, (2018)

Dari tabel diatas dapat dilihat bahwa mayoritas responden berpendidikan terakhir SMA yaitu sebanyak 66 responden $(69.5 \%)$ sedangkan responden berpendidikan terakhir Sarjana/Diploma sebanyak 27 responden (28.4\%) dan responden berpendidikan terakhir SMP memiliki responden paling sedikit yaitu sebanyak 2 responden $(2.1 \%)$. d. Responden Berdasarkan Pekerjaan

Tabel 4.4

Responden Berdasarkan Pekerjaan

\begin{tabular}{|l|c|c|}
\hline \multicolumn{1}{|c|}{ Pekerjaan } & Frekuensi & Persentase \\
\hline PNS & 1 & $1.1 \%$ \\
\hline Pengajar / Guru / Dosen & 1 & $1.1 \%$ \\
\hline Wiraswasta & 4 & $4.2 \%$ \\
\hline Pelajar / Mahasiswa & 79 & $83.1 \%$ \\
\hline Lain-Lain & 10 & $10.5 \%$ \\
\hline Total & 95 & $100 \%$ \\
\hline
\end{tabular}

Dari tabel diatas dapat dilihat bahwa mayoritas profesi responden adalah pelajar atau ,mahasiswa yaitu sebanyak 79 responden (83.1\%). Responden dengan profesi wiraswasta sebanyak 4 responden (4.2\%), responden dengan profesi lain-lain sebanyak 10 responden (10.5\%). Sedangankan responden berprofesi Pengajar, Guru dan Dosen mempunyai frekuenis yang sama dengan PNS yaitu sebanyak 1 responden (1.1\%).

2. Deskripsi Variabel Penelitian

Deskripsi variabel penelitian bertujuan untuk meyajikan gambaran informasi atau deskripsi suatu data variabel dengan karakteristik data yang diperoleh dari hasil penyebaran kuesioner. Dari deskripsi variabel terlihat kecenderungan jawaban semua responden terhadap suatu butir pernyataan kuesioner. Apakah responden cenderung menjawab sangat setuju, setuju, netral, tidak setuju atau sangat tidak setuju. 


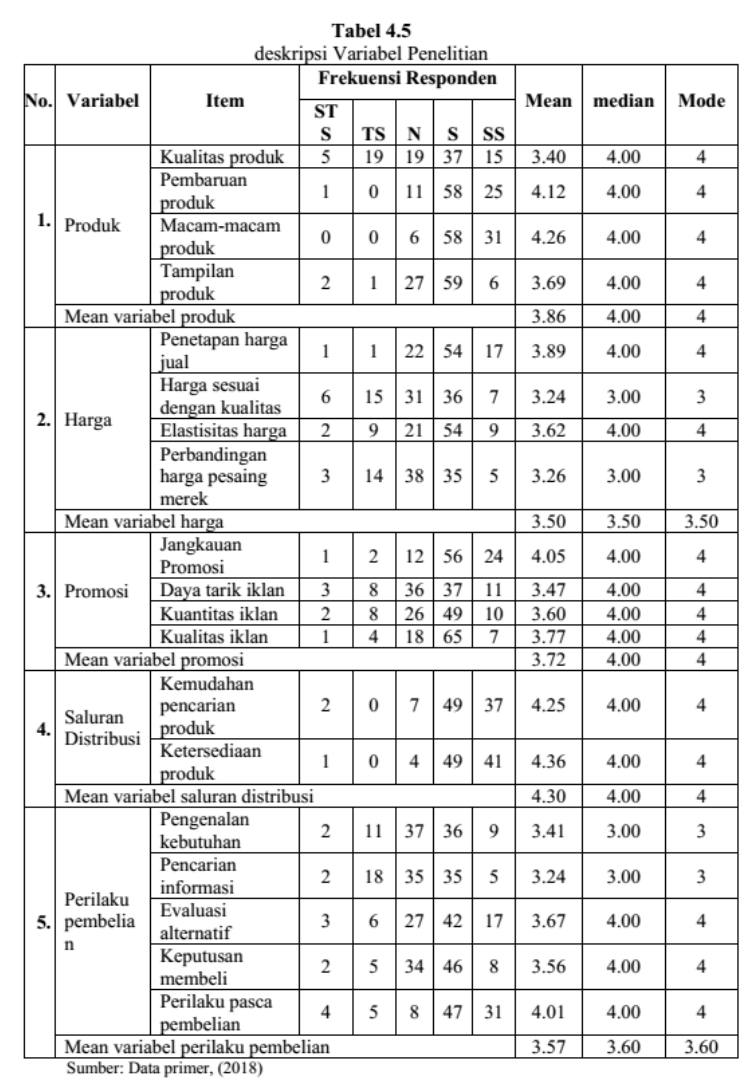

Pada tabel 4.5 dapat dijelaskan bahwa:

a. Variabel produk diperoleh nilai rata-rata sebesar 3.86 pernyataan mengenai pembaruan produk mendapatkan nilai rata-rata tertinggi yaitu sebesar 4.12 sedangkan pernyataan mengenai kualitas produk mendapat nilai rata-rata terendah yaitu sebesar 3.40.

b. Variabel harga diperoleh nilai rata-rata sebesar 3.50 pernyataan mengenai penetapan harga jual mendapatkan nilai rata-rata tertinggi yaitu sebesar 3.89 sedangkan pernyataan mengenai harga sesuai dengan kualitas mendapat nilai rata-rata terendah yaitu sebesar 3.24.

c. Variabel promosi diperoleh nilai ratarata sebesar 3.72 pernyataan mengenai jangkauan promosi mendapatkan nilai rata-rata tertinggi yaitu sebesar 4.05 sedangkan pernyataan mengenai daya tarik iklan mendapat nilai rata-rata terendah yaitu sebesar 3.47.

d. Variabel saluran distribusi diperoleh nilai rata-rata sebesar 4.30 pernyataan mengenai kemudahaan pencarian produk memperoleh nilai rata-rata sebesar 4.25 dan ketersediaan produk mendapatkan nilai rata-rata yaitu sebesar 4.36.

e. Variabel perilaku pembelian diperoleh nilai rata-rata sebesar 3.57 pernyataan mengenai perilaku pasca pembelian mendapatkan nilai ratarata tertinggi yaitu sebesar 4.01 sedangkan pernyataan mengenai pencarian informasi mendapat nilai rata-rata terendah yaitu sebesar 3.24.

\section{Hasil Penelitian}

a. Uji Validitas Variabel Produk $\mathrm{X}_{1}$

Dari variabel produk terdapat 4 pernyataan yang digunakan dalam kuesioner penelitian. Item tersebut terdiri dari X1_1, X1_2, X1_3, X1_4. Setelah diuji dengan metode Confirmatory Factor Analysis (CFA) variabel produk menunjukan 1 komponen yang dapat dilihat pada tabel 4.5.

Table 4.6

Hasil uji validitas variabel Produk $\mathrm{X}_{\mathrm{I}}$

\begin{tabular}{|c|c|}
\hline \multirow{2}{*}{ Item } & Component \\
\cline { 2 - 2 } & 1 \\
\hline $\mathrm{X}_{1} \_1$ & 0.741 \\
\hline $\mathrm{X}_{1} \_$ & 0.827 \\
\hline $\mathrm{X}_{1}{ }_{3}$ & 0.869 \\
\hline $\mathrm{X}_{1}{ } 4$ & 0.531 \\
\hline
\end{tabular}

Sumber: Data Primer, (2018)

Dari hasil output uji validitas variabel Produk X1 dengan menggunakan IBM SPSS Statistic 23.0 dinyatakan 4 item tersebut valid karena nilai Loading Factor pada setiap item lebih dari 0.5. Nilai Loading Factor tertinggi yaitu pada item X1_3 sebesar 0.869 dan nilai Loading Factor terendah yaitu pada item X1_4 sebesar 0.531 .

\section{b. Uji Validitas Variabel Harga $\mathrm{X}_{2}$}

Dari variabel harga terdapat 4 pernyataan yang digunakan dalam kuesioner penelitian. Item tersebut terdiri dari X2_1, X2_2, X2_3, X2_4. Setelah diuji dengan metode Confirmatory Factor Analysis (CFA) variabel harga 
menunjukan 1 komponen yang dapat dilihat pada tabel 4.6

Table 4.7

Hasil uji validitas variabel Harga $\mathrm{X}_{2}$

\begin{tabular}{|c|c|}
\hline \multirow{2}{*}{ Butir Soal } & Component \\
\cline { 2 - 2 } & $\mathbf{1}$ \\
\hline $\mathrm{X}_{2} \_1$ & 0.652 \\
\hline $\mathrm{X}_{2}{ }_{2}$ & 0.805 \\
\hline $\mathrm{X}_{2} 3$ & 0.842 \\
\hline $\mathrm{X}_{2} 4$ & 0.813 \\
\hline
\end{tabular}

Sumher" Data Primer (2018)

Dari hasil output uji validitas variabel harga X2 dengan menggunakan IBM SPSS Statistic 23.0 dinyatakan 4 item tersebut valid karena nilai Loading Factor pada setiap item lebih dari 0.5 . Nilai Loading Factor tertinggi yaitu pada item X2_3 sebesar 0.842 dan nilai Loading Factor terendah yaitu pada item X2_1 sebesar 0.652 .

\section{c. Uji Validitas Variabel Promosi $\mathrm{X}_{3}$}

Dari variabel promosi terdapat 4 pernyataan yang digunakan dalam kuesioner penelitian. Item tersebut terdiri dari X3_1, X3_2, X3_3, X3_4. Setelah diuji dengan metode Confirmatory Factor Analysis (CFA) variabel produk menunjukan 1 komponen yang dapat dilihat pada tabel 4.7.

Table 4.8

Hasil uji validitas variabel Promosi $\mathrm{X}_{2}$

\begin{tabular}{|c|c|}
\hline \multirow{2}{*}{ Butir Soal } & Component \\
\cline { 2 - 2 } & $\mathbf{1}$ \\
\hline $\mathrm{X}_{3} \_1$ & 0.722 \\
\hline $\mathrm{X}_{3}{ }_{2}$ & 0.790 \\
\hline $\mathrm{X}_{3} 3$ & 0.802 \\
\hline $\mathrm{X}_{3} 4$ & 0.764 \\
\hline
\end{tabular}

Sumber: Data Primer, (2018)

Dari hasil output uji validitas variabel saluran distribusi X4 dengan menggunakan IBM SPSS Statistic 23.0 dinyatakan 2 item tersebut valid karena nilai Loading Factor pada setiap item lebih dari 0.5. Dari tabel diatas dijelaskan pada ke 2 item memiliki nilai yang sama yaitu 0.897 .

d. Uji validitas variabel Saluran Distribusi $\mathrm{X}_{4}$

Dari variabel saluran distribusi terdapat 2 pernyataan yang digunakan dalam kuesioner penelitian. Item tersebut terdiri dari X4_1, X4_2, setelah diuji dengan metode Confirmatory Factor Analysis (CFA) variabel saluran distribusi menunjukan 1 komponen yang dapat dilihat pada tabel 4.8 .

Table 4.9

Hasil uji validitas variabel Saluran Distribusi $\mathrm{X}_{4}$

\begin{tabular}{|c|c|}
\hline \multirow{2}{*}{ Butir Soal } & Component \\
\cline { 2 - 2 } & 1 \\
\hline $\mathrm{X}_{4} \_1$ & 0.897 \\
\hline $\mathrm{X}_{4} \_2$ & 0.897 \\
\hline
\end{tabular}

Sumber: Data Primer, (2018)

Dari hasil output uji validitas variabel saluran distribusi X4 dengan menggunakan IBM SPSS Statistic 23.0 dinyatakan 2 item tersebut valid karena nilai Loading Factor pada setiap item lebih dari 0.5. Dari tabel diatas dijelaskan pada ke 2 item memiliki nilai yang sama yaitu 0.897 .

e. Uji validitas variabel Perilaku Pembelian Y

Dari variabel perilaku pembelian terdapat 5 pernyataan yang digunakan dalam kuesioner penelitian. Item tersebut terdiri dari $Y_{-}$1, Y_2, Y_3, Y_4, Y_5. Setelah diuji dengan metode Confirmatory Factor Analysis (CFA) variabel produk menunjukan 1 komponen yang dapat dilihat pada tabel 4.9 
Table 4.10

Hasil uji validitas variabel Perilaku Pembelian Y

\begin{tabular}{|c|c|}
\hline \multirow{2}{*}{ Butir Soal } & Component \\
\cline { 2 - 2 } & $\mathbf{l}$ \\
\hline Y_1 & 0.698 \\
\hline Y_2 & 0.654 \\
\hline Y_3 & 0.901 \\
\hline Y_4 & 0.899 \\
\hline Y_5 & 0.802 \\
\hline
\end{tabular}

Sumber: Data Primer, (2018)

Dari hasil uji validitas variabel Perilaku Pembelian $\mathrm{Y}$ dengan menggunkan IBM SPSS Statistic 23.0 dinyatakan 5 item tersebut valid karena nilai Loading Factor pada setiap item lebih dari 0.5. Nilai Loading Factor tertinggi yaitu pada item Y_3 sebesar 0.899 dan nilai Loading Factor terendah pada item Y_2 sebesar 0.654 .

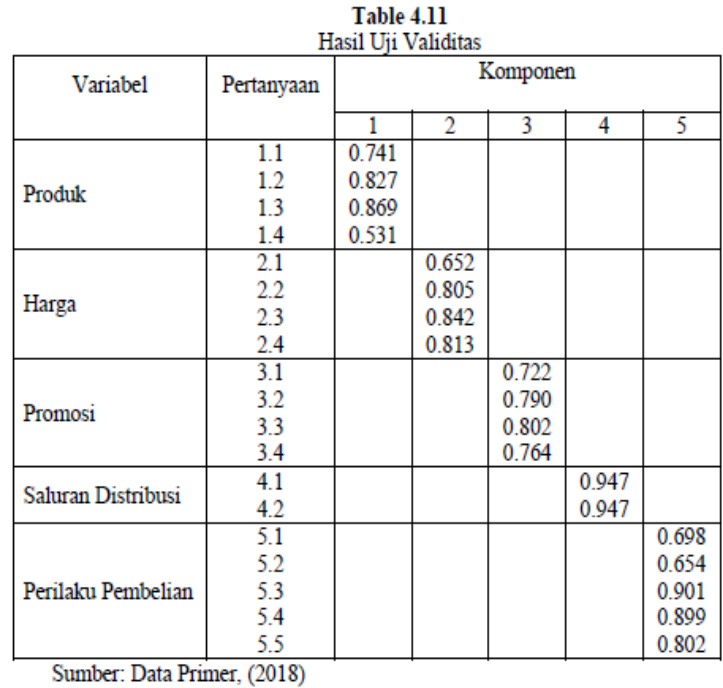

Berdasarkan Tabel 4.6 dapat diketahui semua butir pertanyaan dari 5 (lima) variabel dinyatakan valid, tidak ada butir pernyataan yang dibuang karena nilai Confirmatory Factor Analysis (CFA) lebih besar dari 0,5. Menurut Ghozali (2012:52) kriteria atau syarat suatu item tersebut dinyatakan valid adalah diatas 0,5 dan tingkat signifikansi penelitian adalah berada dibawah 0,05 .

3. Hasil Uji Reliabilitas

Uji reliabilitas dilakukan untuk mengetahui keandalan dari butir-butir instrumen sebelum diadakan pengumpulan data dengan menggunakan Crombach's Alpha. Berdasarkan output IBM SPSS Statistic 23.0 diperoleh Crombach's Alpha untuk kuesioner produk, harga, promosi, saluran dristribusi, dan perilaku pembelian. Hasil pengujian dapat dilihat pada tabel sebagai berikut:

Table 4.12
\begin{tabular}{|l|c|c|}
\hline \multicolumn{1}{|c|}{ Hasil Uji Reliabilitas } \\
\hline Produk & Cronbach's Alpha & Keterangan \\
\hline Harga & 0.693 & Reliabel \\
\hline Promosi & 0.784 & Reliabel \\
\hline Saluran Distribusi & 0.768 & Reliabel \\
\hline Perilaku Pembelian & 0.880 & Reliabel \\
\hline
\end{tabular} Sumber: Data Primer, (2018)
Sur|

Pada Tabel 4.7 dapat diketahui variabel produk, harga, promosi, saluran distribusi dan perilaku pembelian memiliki nilai Crombach Alpha lebih dari 0,6 sehingga variabel produk, harga, promosi, saluran distribusi dan perilaku pembelian reliabel.

4. Hasil Uji Regresi Linier Berganda

Dalam penelitian ini digunakan untuk mengetahui seberapa besar pengaruhnya variabel Produk (X1), Harga (X2), Promosi (X3) dan Saluran Distribusi (X4) terhadap variabel Perilaku Pembelian konsumen mie instan Indomie di Yogyakarta yang dap dilihat dari perhitungan regresi berganda dengan bantuan IMB SPSS Statistic 23.0 yang dapat dilihat pada tabel. 
Tabel. 4.13

Hasil uji hipotesi pada seluruh variabel penelitian

\begin{tabular}{|l|l|c|c|}
\multicolumn{2}{|c|}{ Model } & $\begin{array}{c}\text { Unstandardized } \\
\text { Coefficients } \\
\text { B }\end{array}$ & Sig. \\
\hline 1 & (Constant) & 0.211 & 0.644 \\
& X1 & 0.186 & 0.208 \\
& X2 & 0.175 & 0.147 \\
& X3 & 0.383 & 0.002 \\
& X4 & 0.142 & 0.186 \\
\hline
\end{tabular}

Sumber: Data Primer, (2018)

Berdasarkan hasil pada tabel diatas diperoleh persamaan regresi sebagai berikut:

$\mathrm{Y}=\mathrm{a}+\mathrm{B} 1 \mathrm{X} 1+\mathrm{B} 2 \mathrm{X} 2+\mathrm{B} 3 \mathrm{X} 3, \mathrm{~B} 4+\mathrm{X} 4+\mathrm{e}$ $\mathrm{Y}=0.211+0.186 \mathrm{X} 1+0.175 \mathrm{X} 2+0.383 \mathrm{X} 3$ $+0.142 \mathrm{X} 4+\mathrm{e}$

a. Koefisien regeresi perilaku pembelian (Y) adalah 0.211 yang artinya apabila nilai dari variabel lainnya tetap (konstan) maka keputusan pembelian adalah sebesar 0.211 satuan.

b. Koefisien regresi produk (X1) adalah 0.186 yang artinya setiap kenaikan maupun penurunan nilai produk sebesar 1 satuan dan nilai dari variabel lainnya tetap (konstan), maka perilaku pembelian akan mengalami kenaikan ataupun penurunan 0.186 satuan.

c. Koefisien regresi harga (X2) adalah 0.186 yang artinya setiap kenaikan maupun penurunan nilai harga sebesar 1 satuan dan nilai dari variabel lainnya tetap (konstan), maka perilaku pembelian akan mengalami kenaikan ataupun penurunan 0.186 satuan.

d. Koefisien regresi promosi (X3) adalah 0.383 yang artinya setiap kenaikan maupun penurunan nilai promosi sebesar 1 satuan dan nilai dari variabel lainnya tetap (konstan), maka perilaku pembelian akan mengalami kenaikan ataupun penurunan 0.383 satuan. e. Koefisien regresi saluran distribusi (X4) adalah 0.142 yang artinya setiap kenaikan maupun penurunan nilai saluran distribusi sebesar 1 satuan dan nilai dari variabel lainnya tetap (konstan), maka perilaku pembelian akan mengalami kenaikan ataupun penurunan 0.142 satuan.

\section{Uji Signifikansi Parameter Individual (Uji t)}

Uji signifikansi individual digunakan untuk menguji suatu variabel bebas produk (X1), harga (X2), promosi (X3) dan saluran distribusi (X4) berpengaruh atau tidak terhadap variabel terikatnya yaitu perilaku pembelian konsumen.

\begin{tabular}{|c|c|}
\hline \multirow{2}{*}{ Variabel } & Hasil Uji \\
\hline & Signifikansi \\
\hline Produk & 0.208 \\
\hline Harga & 0.147 \\
\hline Promosi & 0.002 \\
\hline Saluran Distribusi & 0.186 \\
\hline
\end{tabular}

Sumber: Data primer, (2018)

Berdasarkan data diatas, maka hasil uji pada penelitian ini dapat dijelaskan sebagai berikut:

a. Variabel Produk

Ha: Terdapat pengaruh positif signifikan antara variabel produk (X1) terhadap perilaku pembelian (Y) pada produk mie instan Indomie di Yogyakarta.

H0: Tidak terdapat pengaruh yang signifikan antara variabel produk (X1) terhadap perilaku pembelian produk mie instan Indomie di Yogyakarta.

Dilihat dari nilai sign hitung > alpha (0.05) pada tabel diatas nilai sign hitung yang diperoleh sebesar 0.208 hal ini menunjukan bahwa nilai sign hitung 0.208 $>0.05$, maka dapat disimpulkan bahwa hipotesis H1 ditolak dan H0 diterima. Yang berarti bahwa tidak terdapat pengaruh positif signifikan antara variabel produk (X1) terhadap perilaku pembelian (Y) pada produk mie instan Indomie di Yogyakarta. 
b. Variabel Harga

Ha: Terdapat pengaruh positif signifikan antara variabel harga (X2) terhadap perilaku pembelian (Y) pada produk mie instan Indomie di Yogyakarta.

H0: Tidak terdapat pengaruh yang signifikan antara variabel harga (X2) terhadap perilaku pembelian (Y) produk mie instan Indomie di Yogyakarta.

Dilihat dari nilai sign hitung > alpha (0.05) pada tabel diatas nilai sign hitung yang diperoleh sebesar 0.147 hal ini menunjukan bahwa49 nilai sign hitung $0.147>0.05$, maka dapat disimpulkan bahwa hipotesis $\mathrm{H} 2$ ditolak dan $\mathrm{H} 0$ diterima. Yang berarti bahwa tidak terdapat pengaruh positif signifikan antara variabel harga (X2) terhadap perilaku pembelian (Y) pada produk mie instan Indomie di Yogyakarta.

\section{c. Variabel Promosi}

Ha: Terdapat pengaruh positif signifikan antara variabel promosi (X3) terhadap perilaku pembelian (Y) pada produk mie instan Indomie di Yogyakarta.

H0: Tidak terdapat pengaruh yang signifikan antara variabel promosi (X3) terhadap perilaku pembelian (Y) produk mie instan Indomie di Yogyakarta.

Dilihat dari nilai sign hitung < alpha (0.05) pada tabel diatas nilai sign hitung yang diperoleh sebesar 0.002 hal ini menunjukan bahwa nilai sign hitung 0.002 $<0.05$, maka dapat disimpulkan bahwa hipotesis H3 diterima dan H0 ditolak. Yang berarti bahwa terdapat pengaruh positif signifikan antara variabel promosi (X3) terhadap perilaku pembelian (Y) pada produk mie instan Indomie di Yogyakarta.

\section{d. Variabel Saluran Distribusi}

Ha: Terdapat pengaruh positif signifikan antara variabel produk (X1) terhadap perilaku pembelian (Y) pada produk mie instan Indomie di Yogyakarta.

H0: Tidak terdapat pengaruh yang signifikan antara variabel saluran distribusi (X4) terhadap perilaku pembelian (Y) produk mie instan Indomie di Yogyakarta.

Dilihat dari nilai sign hitung > alpha (0.05) pada tabel diatas nilai sign hitung yang diperoleh sebesar 0.186 hal ini menunjukan bahwa nilai sign hitung 0.186 $>0.05$, maka dapat disimpulkan bahwa hipotesis $\mathrm{H} 4$ ditolak dan $\mathrm{H} 0$ diterima. Yang berarti bahwa tidak terdapat pengaruh positif signifikan antara variabel saluran distribusi (X4) terhadap perilaku pembelian (Y) pada produk mie instan Indomie di Yogyakarta.

\section{Uji Signifikan Simultan (Uji F)}

Hasil uji signifikansi simultan (uji f)

\begin{tabular}{|l|l|c|c|}
\hline \multicolumn{2}{|c|}{ Model } & F & Sig. \\
\hline 1 & Regression & 15.481 & $.000^{\mathrm{b}}$ \\
\hline
\end{tabular}

Sumber: Data prime, (2018)

Berdasarkan hasil uji simultan dari tabel diatas menunjukan bahwa $\mathrm{f}$ hitung sebesar 15.481 dan uji diatas didapatkan nilai signifikansi 0.000 (sign $0.000<$ 0.05), dapat disimpulkan bahwa produk (X1), harga (X2), promosi (X3) dan saluran distribusi (X4) secara bersamasama memiliki pengaruh yang positif signifikan terhadap keputusan pembelian (Y).

\section{Uji Determinasi (R2)}

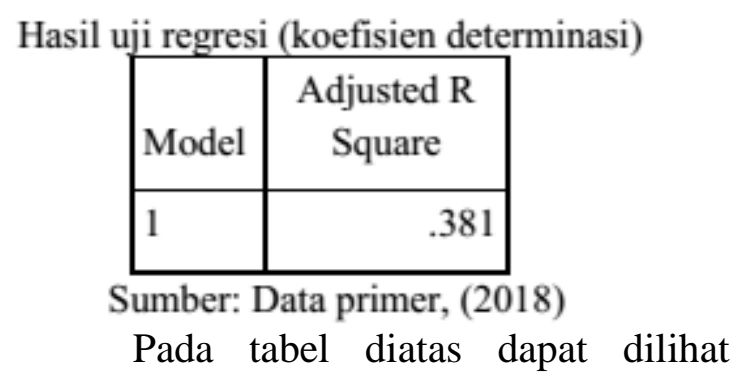
bahwa nilai Adjusted R2 adalah sebesar 0.381. hal ini dapat diartikan bahwa variabel independen produk (X1), harga (X2), promosi (X3) dan saluran distribusi (X4) dapat menjelasan variabel dependen 
perilaku pembelian (Y) sebesar $38.1 \%$, sedangkan sisanya $61.9 \%$ diterangkan oleh faktor lain yang tidak diteliti.

\section{Pembahasan}

Penyataan hipotesis pertama bahwa produk berpengaruh positif dan signifikan terhadap perilaku pembelian konsumen mie instan Indomie di Yogyakarta tidak terbukti. Hal ini diduga karena kualitas produk yang ditawarkan memiliki kesamaan yang dengan produk lain sehingga faktor produk tidak menjadi pertimbangan konsumen untuk melakukan keputusan pembelian, jadi walaupun konsumen mempunyai persepsi positif terhadap faktor produk yang ditunjukan dengan nilai rata-rata skor sebesar 3.86 tetapi karena cenderung sama dengan pesaing serupa maka variabel produk tidak memiliki pengaruh positif dan52 signifikan terhadap perilaku pembelian konsumen mie instan Indomie di kota Yogyakarta.

Penyataan hipotesis kedua bahwa harga berpengaruh positif dan signifikan terhadap perilaku pembelian konsumen mie instan Indomie di Yogyakarta tidak terbukti. Hal ini karena umumnya konsumen menghendaki harga yang terjangkau oleh mereka dan manfaat yang didapatkannya sesuai dengan pengorbanan yang mereka keluarkan. Dari hasil penelitian bahwa rata-rata skor tertinggi adalah pada penetapan harga jual yang terjangkau yaitu sebesar 3.89 dan rata-rata skor terendah adalah pada kesesuaian harga dengan manfaat yang diterima konsumen yaitu sebesara 3.24. Dalam hal ini dapat dikatakan bahwa harga jual yang diberikan tidak sesuai dengan manfaat yang diterima konsumen walaupun sebenarnya harga yang terjangkau juga dapat mendorong keputusan pembelian. Namun faktor ini juga dapat dipengaruhi oleh persaingan harga dengan produk lain yang sejenis.

Penyataan hipotesis ketiga bahwa promosi berpengaruh positif dan signifikan terhadap perilaku pembelian konsumen mie instan Indomie di Yogyakarta terbukti. Hal ini terjadi karena jangkauan iklan yang sangat luas dengan begitu pihak perusahaan berhasil menginformasikan keunggulan produknya dan merangsang atau membujuk masyarakat untuk membeli produknya. Hal ini juga terlihat dari skor rata-rata tertinggi yaitu pada jangkauan promosi yaitu sebesar 4.05 dan skor ratarata terendah pada daya tarik iklan yaitu sebesar 3.47.

Penyataan hipotesis keempat bahwa saluran distribusi berpengaruh positif dan signifikan terhadap perilaku pembelian konsumen mie instan di Yogyakarta tidak terbukti. Hal ini mengindikasikan bahwa tempat atau lokasi keberadaan mie instan Indomie menjadi perhitungan bagi konsumen untuk melakukan keputusan pembelian. Pelanggan atau konsumen memperhitungkan jauh-dekat serta mudah tidaknya lokasi mie instan Indomie untuk dicapai. Karena jika mie instan Indomie sulit untuk dicari dan sulit didapatkan akan mempengaruhi keputusan pembelian konsumen. Jadi walaupun konsumen mempunyai persepsi positif terhadap faktor saluran distribusi yang ditunjukan dengan nilai rata-rata skor sebesar 4.30 tetapi karena cenderung sama dengan pesaing serupa yang mudah didapatkan produkny maka variabel saluran distribusi tidak memiliki pengaruh positif dan signifikan terhadap perilaku pembelian konsumen mie instan Indomie di kota Yogyakarta.

Berdasarkan hasil uji simultan menunjukan bahwa $\mathrm{F}$ hitung sebesar 15.481 dan pada uji $\mathrm{F}$ didapatkan dengan taraf signifikansi 0.05 (sig $0.000<0.05$ ), dapat disimpulkan bahwa variabel produk (X1), harga (X2), promosi (X3) dan saluran ditribusi (X4) secara bersamamasa memiliki pengaruh yang signifikan terhadap perilaku pembelian (Y) konsumen mie instan Indomie di kota Yogyakarta. 


\section{KESIMPULAN DAN SARAN}

\section{Kesimpulan}

Berdasarkan hasil penelitian yang dilakukan, maka dapat diambil

kesimpulan sebagai berikut:

1. Variabel produk tidak berpengaruh positif terhadap perilaku pembelian konsumen mie instan Indomie di Yogyakarta dengan begitu hipotesis $\mathrm{H} 0$ diterima dan $\mathrm{Ha}$ ditolak yang berarti bahwa tidak terdapat pengaruh positif dan signifikan antara variabel Produk (X1) terhadap perilaku pembelian (Y) konsumen mie instan Indomie di Yogyakarta.

2. Variabel harga tidak berpengaruh positif terhadap perilaku pembelian konsumen mie instan Indomie di Yogyakarta dengan begitu hipotesis $\mathrm{H} 0$ diterima dan Ha ditolak yang berarti bahwa tidak terdapat pengaruh positif dan signifikan antara variabel Harga (X2) terhadap perilaku pembelian (Y) konsumen mie instan Indomie di Yogyakarta.

3. Variabel promosi berpengaruh positif terhadap perilaku pembelian konsumen mie instan Indomie di Yogyakarta dengan begitu hipotesis $\mathrm{H} 0$ ditolak dan Ha diterima yang berarti bahwa terdapat pengaruh positif dan signifikan antara variabel Promosi (X3) terhadap perilaku pembelian (Y) konsumen mie instan Indomie di Yogyakarta. Dengan demikian $\mathrm{H} 3$ diterima.

4. Variabel saluran distribusi tidak berpengaruh positif terhadap perilaku pembelian konsumen mie instan Indomie di Yogyakarta dengan begitu hipotesis $\mathrm{H} 0$ diterima dan $\mathrm{Ha}$ ditolak yang berarti bahwa tidak terdapat56 pengaruh positif dan signifikan antara variabel saluran distribusi (X4) terhadap perilaku pembelian (Y) konsumen mie instan Indomie di Yogyakarta.

5. Variabel produk, harga, promosi dan saluran distribusi berpengaruh positif terhadap perilaku pembelian konsumen mie instan Indomie, dapat disimpulkan bahwa faktor produk (X1), harga (X2), promosi (X3) dan saluran distribusi (X4) secara bersama-sama memiliki pengaruh yang signifikan terhadap perilaku pembelian..

\section{Saran}

Berdasarkan hasil pembahasan dan kesimpulan yang diperoleh maka dapat diajukan beberapa sarang yaitu:

1. Perusahaan sebaiknya mingkatkan kualitas produk agar senantiasa mampu memenuhi kebutuhan para konsumen di kota Yogyakarta khususnya yang telah dikenal baik oleh masyarakat.

2. Perusahaan sebaiknya memberikan harga yang mampu bersaing dan sesuai dengan manfaat yang diterima konsumen.

3. Perusahaan harus mendistribusikan produknya dengan merata agar setiap masyarakat di kota Yogyakarta dapat menikmati mie instan Indomie dengan begitu mie instan Indomie selalu menjadi pilihan konsumen dalam setiap keputusan pembelian yang dilakukan konsumen..

4. Diharapkan penelitian selanjutnya untuk mengamati variabel lain atau dapat menambahkan variabel diluar variabel dalam penelitian ini.

5. Diharapkan dalam penelitian selanjutnya dapat menambahkan data pendapatan reponden.

\section{DAFTAR PUSTAKA}

Adhilla, Fitroh dan Deny Ismanto.2015. Analisis Multivariate. Yogyakarta: Fakultas Ekonomi Univerita Ahmad Dahlan.

Adhilla, Fitroh, Dyah Fitriani, dan Deny Ismanto. 2015. Statistik 2. Yogyakarta: Fakultas Ekonomi Univeritas Ahmad Dahlan 
Algifari. 2013. Statistika Induktif: untuk Ekonomi dan Bisnis. Yogyakarta: Sekolah Tinggi Ilmu Manajemen YKPN.

Andanawari, Anindya Rachma. 2014. Pengaruh Harga, Lokasi dan Kualitas Produk Terhadap Keputusan Pembelian (Studi Kasus Pada Stove Syndicate Café Semarang). Universitas Diponegoro.

Angipora, M. P. 2002. Dasar-dasar Pemasaran. Edisi Pertama. Cetakan Pertama.Jakarta: PT. Raja Grafindo Persada.

Angipora, M. P. 2007. Dasar-dasar Pemasaran. Edisi Kedua. Jakarta: PT. Raja Grafindo Persada.

Basu Swastha. 2002. Manajemen Pemasaran. Edisi Kedua. Cetakan Kedelapan. Jakarta: Liberty.

Ghozali, Imam. 2012. Aplikasi Analisis Multivariate dengan Program IBM SPSS 20. Semarang: Badan Penerbit Universitas Diponegoro.

Ghozali, Imam. 2012. Aplikasi Analisis Multivariate dengan Program IBM SPSS 19. Edisi Kelima. Semarang: Badan Penerbit Universitas Diponegoro.

Ghozali, Imam. 2001. Aplikasi Analisis Multivariate dengan Program IBM SPSs. Semarang: Badan Penerbit Universitas Diponegoro.

Gitosudarmo, I. 2000. Manajemen Pemasaran. Edisi Pertama. Cetakan Keenam. Yogyakarta : BPFE.

Gitosudarmo, I. 2008. Manajemen Pemasaran. Cetakan Keempat. Yogyakarta : BPFE.
Husein, Umar. 2000. Riset Pemasaran Dan Penilaian Konsumen. Jakarta: PT Gramedia Pustaka. Kotler, Philip dan Kevin Lane Keller. 2009. Manajemen Pemasaran. Jilid I. Edisi ke 13. Jakarta: Erlangga.

Kotler, Philip dan Gary Amstrong. 2012. Principles of Marketing. England: Pearson Education Limited.

Kotler, Philip dan Gary Amstrong. 2001. Prinsip-Prinsip Pemasaran. Edisi ke12 Jilid 2. Jakarta: Erlangga.

Ong, Ian Antonius dan Sugiono Sugiharto. 2013. "Analisa Pengaruh Strategi Diferensiasi, Citra Merek, Kualitas Produk, dan Harga Terhadap Keputusan Pembelian Pelanggan di Cincau Station Surabaya". Jurnal Manajemen Pemasaran, Vol 1:2.

Stanton, W.J.1996. Prinsip Pemasaran. Jilid II. Edisi VII. Jakarta: Erlangga.

Sugiyono. 2017 Metode Penelitian Bisnis: Pendekatan Kuantitatif, Kualitatif, Kombinasi, dan R\&D. Bandung : Alfabeta.

Sugiyono. 2012. Metode Kuantitatif, Kualitatif, dan R\&D. Bandung : Alfabeta.

Sugiyono. 2010. Metode Penelitian Pendidikan Pendekatan Kuantitatif, kualitatif, dan R\&D. Bandung: Alfabeta

Sujarwati. 2013. Pengaruh Kualitas Pelayanan, Kualitas Produk dan Keuntungan Terhadap Pemilihan Produk Pembiayaan Murabahah Di PT.BPR Syari'ah Mitra Cahaya Indonesia Yogyakarta. Yogyakarta: UIN Sunan Kalijaga 
Sunyoto ， Danang. 2012. Metodologi Penelitian Ekonomi. Cetakan Pertama. Yogyakarta : CAPS.

Suryani, Tatik. 2013. Perilaku Konsumen di Era Internet. Yogyakarta: Graha Ilmu

Tan, Erwin Rediono. 2001 "Pengaruh Faktor Harga, Promosi Dan Pelayanan Terhadap Keputusan Konsumen Untuk Berbelanja di Alfamart Surabaya". Jurnal Kewirausahaan, Vol 5 No 2.

Tjiptono, fandy. 2008. Strategi Pemasaran. Edisi 3. Yogyakarta: Andi.

Wulandari, Desi. 2015. Pengaruh Harga, Produk, Lokasi dan Fasilitas Terhadap Keputusan Pembelian Busana Muslim Di Yogyakarta: Studi Kasus Pada Konsumen Aisya Yogyakarta. Yogyakarta: UIN Sunan Kalijag 